\title{
Rethinking Education in the New Normal Post-COVID-19 Era: A Curriculum Studies Perspective
}

\author{
Michael B. Cahapay ${ }^{1 *}$
}

${ }^{1}$ College of Education, Mindanao State University, Fatima, General Santos City, PHILIPPINES
${ }^{*}$ Corresponding Author: mbcahapay@up.edu.ph

Citation: Cahapay, M. B. (2020). Rethinking Education in the New Normal Post-COVID-19 Era: A Curriculum Studies Perspective. Aquademia, 4(2), ep20018. https://doi.org/10.29333/aquademia/8315

\section{ARTICLE INFO}

Received: 28 May 2020

Accepted: 29 May 2020

\begin{abstract}
All sectors worldwide, including education, have been devastated by the impacts of COVID-19 pandemic. As we approach the new normal in the post-COVID-19 era, there is a need to consider education anew in the light of emerging opportunities and challenges. Thus, this short article attempts to rethink education in the new normal post-COVID-19 era through the perspectives of curriculum studies. The implications of the continuing crisis to the four elements of curriculum - goal, content, approach, and evaluation - are discussed. Some emerging options may be cogently viewed within the perspectives of these elements. Aside from the lens curriculum studies, this paper suggests that other aspects of education should be explored further to better reconsider education in this new era in human history.
\end{abstract}

Keywords: education, new normal, COVID-19, curriculum studies

\section{INTRODUCTION}

COVID-19 was first experienced in Wuhan, China in late December 2019 (Shereen et al., 2020). A highlight of COVID19 timeline shows that on January 13, 2020, the first coronavirus infection outside China was reported; February 02, 2020, the first coronavirus mortality outside China was recorded; March 11, 2020, the World Health Organization announced the outbreak a pandemic spreading to different continents; April 10, 2020, the global death toll surpassed a hundred thousand; May 11, 2020, countries like Spain, New Zealand, Thailand, and Iran began to ease their quarantine restrictions after a decrease (Secon et al., 2020).

Educational systems are likewise preparing for the postCOVID-19 era characterized by "new normal." This expression first emerged in the field of business. It was used to caution the belief of economists that industrial economies would revert to normal after the recession (El-Erian, 2010). The term has since been used in different contexts to mean that something which was previously not typical has become typical. The Urban Dictionary (2009) described "new normal" as the situation of being after some intense change has occurred. It substitutes the accepted, habitual, usual state after a certain event happened.

Several scholarly works have been recently published to tackle the multidimensional implications of COVID-19 crisis to the expected new normal period (e.g. see Sintema, 2020a \&
Toquero, 2020 on educational; Radwan \& Radwan, 2020 on social and economic; Usak et al., 2020 on social and psychological). Within the educational dimension, there has been extensive researches discussing the adoption of online modality in instructional implementation in the new normal post-COVID-19 era (e.g. see Sintema, 2020b on digitalized virtual classroom; Basilaia \& Kvavadze, 2020 on online education; Naciri et al., 2020 on mobile learning; Mulenga \& Marbán, 2020 on digital learning).

These emerging discussions as regards education in the new normal post-COVID-19 era could be reconsidered through the lens of curriculum studies. A curriculum can be defined as a plan that has elements. Based on the seminal curriculum development models (e.g. Tyler, 1949; Taba, 1962), these elements of the curriculum are the goal, content, approach, and evaluation. Drawing notions from this perspective, a curriculum development in any period and circumstance needs to look at these four elements.

Considering the approaching new normal post-COVID-19 period, a rethinking of education within the curriculum studies perspectives is important. It presents glimpses of opportunities and challenges in the future of education as far as curriculum is concerned. By discussing the curriculum possibilities in terms of goal, content, approach, and evaluation, educators in the field will be better informed of the key problems, decisions, and solutions that must be cogently considered as we approach the new era. 
Thus, this paper attempted to rethink education in the new normal post-COVID-19 era from the perspective of curriculum studies.

\section{RETHINKING EDUCATION IN THE NEW NORMAL POST-COVID-19 ERA}

\section{A Focus on Preparedness as a Goal}

The new normal post-COVID-19 era opens an opportunity for rethinking the goals of education. One of the goals to make the curriculum relevant, appropriate, and responsive is the development of preparedness in times of disasters, diseases, and emergencies. There are existing curriculum goals that touch on a set of preparedness competencies in the different fields of study. However, the focus of these goals is specifically on natural disaster preparedness. Considering the coming new normal post-COVID-19 period, there is a desire for a more focused goal on preparedness in terms of global disease outbreaks.

When formulating the goal of preparedness, there is a need to define it. However, it appears that an agreed definition of preparedness is a challenge such as its current state in the medical education (McCabe et al., 2010; Nelson et al., 2007). It seems to remain a vague concept in which its terrains have not been defined well. It is common though to meet the related terms such as health preparedness (Khan et al., 2018), emergency preparedness (Gebbie \& Qureshi, 2002), and disaster preparedness (Kent, 1994).

There has been a call to integrate preparedness content into the curriculum. Basic education schools have realistically incorporated preparedness frameworks in their curriculum in recent years. In many countries like the Philippines, preparedness as a goal of education for young learners has been given attention (Kagawa \& Selby, 2014; Valencia et al., 2018). However, as preparedness is still a muddy juncture, it is unknown if preparedness across different types of disasters, diseases, and emergencies are the same. It should be noted that in the new normal post-COVID-19 period, there is a need to contextualize such preparedness goal within the pandemic perspectives.

When it comes specifically to higher education, efforts to expand the role of nursing in responding to global disease outbreaks have been placed (Corless et al., 2018). Goal related to preparedness has also been started in other higher education fields (e.g. see Uhernik, 1998 in counselor education; Kaslow, 2004 in professional psychology; Ng, 2012 in social work). These efforts should be strengthened on a larger scale and to more fields such as teacher education, agricultural extension, transportation studies, allied health, and other fields related to social services in the new normal period.

The COVID-19 pandemic undeniably caught education systems and learners off guard. This situation revealed gaps in the curriculum. One of the steps to address this gap is to develop a set of preparedness competencies forming a goal of the curriculum.

\section{Between Integration and Reduction of Content}

With the restrictions brought by COVID-19, a new normal curriculum may also adopt the integration of content. This approach makes it possible to reduce the number of hours spent on all the subjects but still addressing all the curriculum expectations. This strategy will enable the assimilation of curriculum content expectations from various subjects in designing an instruction (Romano et al., 2012). For example, in teaching literature, science, and history, contents may be integrated by going through historical periods and focus on scientific inventions and literary works during each period.

Fogarty and Stoehr (1991) suggested a range of integration models. They introduced ten integration models such as fragmented, connected, nested, sequenced, shared, webbed, threaded, integrated, immersed, and networked. These models require the assimilation of skills and concepts from various subjects or disciplines within a curriculum. It could be a good strategy for educators to reduce curriculum pressures to cover all content amid the continuing restrictions.

Aside from integrating the content, some educational systems are also contemplating to reduce the curriculum content. They want to teach content that is "essential" and remove content that is not. However, one major problem in this proposal lies in the question: How do we define "essential" content? Print (1993) advised that in selecting content, one must observe several considerations. Within the current global COVID-19 outbreak, the following three considerations are suggested by the researcher:

1. Significance. The criterion of significance applies where content is considered in terms of how fundamental it is to the theme under study. Where the content is contemplated as valuable to the subject, it is deemed significant, thus recommended for inclusion in a curriculum.

2. Relevance. This criterion is anchored on the reality that content should be related to the perspectives of the community values, aspirations, principles, and problems that would help learners become effective citizens.

3. Utility. Curricularists should consider two usefulness of the content: current and future. There is some content that learners need to learn to apply in the immediate present and other content to prepare them to deal with the future.

The coming new normal post-COVID-19 era can be a teachable moment for content that is significant, relevant, and useful. For instance, Gonser (2020) specifically suggested simple content such as "why hygiene matters" and "how germs spread" to more complex ones like "ethical decisions, the science behind how viral infections work, or the mathematics underpinning pandemics." Flannery (2020) interviewed teachers who integrated relevant content. One teacher began work with her students a topic on coronavirus vaccines in animals which is a relevant topic both in the general situation and ranching societies. Another teacher focused on teaching a new normal behavior called social distancing. These are examples of contents that are relevant in the new normal postCOVID-19 era. 
The COVID-19 condition itself is indeed reorganizing the content of the curriculum. Between integration and reduction of content, educators should carefully weigh each option without sacrificing much of the knowledge that is worth teaching to the learners.

\section{A Range of Teaching Approaches}

Furthermore, many educational systems are contemplating responsive approaches to implement the curriculum. Most of them are looking into the role of technology. During an era of social distancing practice demonstrating a major new normal behavior, many schools are headed towards complete online modality or blended learning modality in instruction.

The complete online modality of the instructional approach during the post-COVID-19 era can be feasible. For example, in China that was the first epicenter of the virus, more than 180 million children were ordered to remain at home. But while schools were closed for quarantine, education had to continue but this time in an altered modality. It was implemented online through a variety of online courses and electronic textbooks (Patrinos \& Shmis, 2020).

Moreover, blended learning is coincidentally known as the "new normal" (Norberg et al., 2011) in the realm of educational technology. Though there are obscurities in its definition, blended learning can be commonly described as an instructional approach that integrates traditional classroom methods and online digital methods (Graham 2013). It necessitates the physical presence of both teacher and learner, with features of learner control over time, setting, or pace (Huang et al., 2009). Given these features of blended learning, it provides auspicious prospects for use in education come new normal times.

While complete online and blended learning sound like the "holy grail" in this new era in education, it requires massive changes. For some developed countries, blended learning is an established educational modality. It has enabled these countries to cope with the impacts of the current COVID-19 plague. Online learning and teaching are supported by developed structures and trained teachers (Olivier, 2020). However, for other countries, schools must carefully plan virtual learning solutions. It requires an assessment of their capabilities based on the reliability of local power supplies, internet connectivity, and readiness of the teachers (Obana, 2020).

Blended learning still requires an amount of traditional classroom modality. Considering the social distancing practice in this new era, group work approaches that require interactions with close physical contacts such as formal and informal cooperative learning groups, think-pair-share, peer instruction, and jigsaw, (Brame \& Biel, 2015) might just be modified or reduced, if not eliminated, from the options of instructional methods of teaching.

On the other hand, there can be more use of methods that require less movement and physical contact. One method is direct instruction. It is an instructional approach that is planned, sequenced, and managed by the teachers. The implementation of instruction to learners is attained mainly through strategies like lectures or demonstrations. With this method, teachers generally direct the process (The Glossary of Educational Reform, 2013), thus keeping students less active.

The COVID-19 global outbreak is evidently redefining the approaches to instructional implementation. The range of options that education systems are contemplating presents not only opportunities but also challenges that must be considered in the process.

\section{Reminders on Instructional Evaluation}

The closure of many educational systems coincided with the student evaluation period in schools. As a result, we have seen different instructional evaluation practices that have been adopted as a response to the COVID-19 crisis. These practices are likely to be part of the new normal in education. Many schools have issued implementing guidelines changing many aspects of the evaluation component of the curriculum. This time is indeed a new period in the curriculum.

There is massive replication of instructional evaluation to online. Within the online instructional evaluation, there are synchronous and asynchronous forms. The synchronous form requires the teacher and the student to work together at an arranged time through online applications like Zoom. It can also be achieved, for example, through phone in which the teacher provides assessment to the learners in real time. The asynchronous form, on the other hand, is the form in which the teacher and learners do not need to interact online in a live manner. They are separated into different spaces and times. A tool that is used to accomplish this assessment form is Moodle in which teacher posts assessment tasks for learners (Liberman et al., 2020).

When it comes to the grading system, it has been also observed that many schools have decided to change their assessment scales from quantitative to qualitative such as pass or fail system (Farrington, 2020). While the decision is supported by admirable intentions, some people worry about its effects. The advantages and disadvantages of different assessment scales are debated in the context of student motivation (Barnes \& Buring, 2012). Within the argument favoring quantitative over qualitative, Dilanchyan (2020) critiqued that such change would detach the motivation that students need to strive for high grades.

While the usual quantitative assessment practice is expected to be still the dominant practice in the new normal, however, with the continuing global crisis, there will likely be a propensity towards forms of error in the school assessment systems. Considering the difficult circumstance of the learners, the assessment construct called leniency error is a situation where the teacher tends to be too "generous" and all students are given high passing scores (Nitko \& Brookhart, 2014). It is considered as one of the threats to the reliability of student performance which some education stakeholders expressed worries about.

The COVID-19 crisis is continuously reshaping instructional evaluation. The massive migration of learner assessment to online and the adjustments to grading systems are inevitable. With these changes, educators are encouraged to maintain high quality assessment. 


\section{CONCLUSION}

The unprecedented impacts of the COVID-19 global outbreak are indeed ushering educational systems to a new normal period in human history. This paper attempted to rethink education in the new normal post-COVID-19 era from the perspective of curriculum studies.

A curriculum goal that must be emphasized in the new normal curriculum is to develop preparedness competencies among the learners. When it comes to curriculum content, there are challenges to whether to integrate or reduce. On the other hand, instructional approaches mostly shifting to online modality should be considered in the light of different factors. As regards instructional evaluation, some concerns related to the assessment of learning present cogent reminders for educators.

This paper offers an insight into how curriculum can be reshaped, considering the new normal post-COVID-19 era. Other researches should look into other aspects of education from a wider perspective. The COVID-19 pandemic affects political, economic, social, and psychological dimensions. These dimensions continuously tackled in the emerging studies should be further examined to better prepare education systems in the new period in human history.

\section{REFERENCES}

Barnes, K. D., \& Buring, S. M. (2012). The effect of various grading scales on student grade point averages. American Journal of Pharmaceutical Education, 76(3), 41. https://doi.org/10.5688/ajpe76341

Basilaia, G., \& Kvavadze, D. (2020). Transition to online education in schools during a SARS-CoV-2 Coronavirus (COVID-19) pandemic in Georgia. Pedagogical Research, 5(4), em0060. https://doi.org/10.29333/pr/7937

Brame, C. J., \& Biel, R. (2015). Setting up and facilitating group work: Using cooperative learning groups effectively. Vanderbilt University. Retrieved from http://cft.vanderbilt. edu/guides-sub-pages/setting-up-and-facilitating-groupwork-using-cooperative-learning-groups-effectively/

Corless, I. B., Milstead, J. A., \& Kirksey, K. M. (2018). Expanding nursing's role in responding to global pandemics. Nursing Outlook, 66(4), 412-415. https://doi.org/10.1016/j.outlook.2018.06.003

Dilanchyan, H. (2020, March 31). The pass/fail grading system could severely affect your GPA. Chimes. Retrieved from https://chimesnewspaper.com/47867/opinions/the-passfail-grading-system-could-severely-affect-your-gpa/

Direct instruction [Def.1 \& 2] (2013). In The Glossary of Educational Reform. Retrieved on May 22, 2020 from https://www.edglossary.org/direct-instruction/

El-Erian, M.A. (2010). Navigating the new normal in industrial countries. Washington D.C.: International Monetary Fund.
Farrington, R. (2020, March 30). Colleges go to pass-fail due to Coronavirus concerns: What does this mean for students. Forbes. Retrieved from https://www.forbes.com/sites/ robertfarrington/2020/03/30/colleges-go-to-pass-fail-due -to-coronavirus-concerns-what-does-this-mean-forstudents/\#620c39aa7eaa

Flannery, M. E. (2020). How teachers are integrating COVID19 crisis into their lessons. NEA Today. Retrieved from http://neatoday.org/2020/04/22/teaching-aboutcoronavirus/

Fogarty, R., \& Stoehr, J. (1991). Integrating curricula with multiple intelligences: Teams, themes, and threads. Palatine, IL: Skylight Publishing, Inc.

Gebbie, K. M., \& Qureshi, K. (2002). Emergency and disaster preparedness: core competencies for nurses. American Journal of Nursing. 102(1), 46-51. https://doi.org/10.1097/ 00000446-200201000-00023

Gonser, S. (2020). Innovative ways to make Coronavirus a teachable moment. Edutopia. Retrieved from https://www.edutopia.org/article/innovative-ways-makecoronavirus-teachable-moment

Graham, C. R. (2013). Emerging practice and research in blended learning. In M. G. Moore (Ed.), Handbook of distance education, (3rd ed., pp. 333-350). New York: Routledge.

Huang, R. M., Lanqin, Z., \& Haisen, Z. (2009). The theory of curriculum design based on blended learning. E-education Research, 9-14. https://doi.org/10.1007/978-3-540-851707_6

Kagawa, F., \& Selby, D. (2015). Disaster risk reduction in the school curriculum: The present and potential role of development agencies and the implications for the Hyogo Framework for Action 2005-2015 Successor (Unpublished Report). Retrieved from https://www.preventionweb.net/ english/hyogo/gar

Kaslow, N. J. (2004). Competencies in professional psychology. American Psychologist, 59(8), 774-781. https://doi.org/ 10.1037/0003-066X.59.8.774

Kent, R. (1994). Disaster preparedness. United Nations Disaster Management Training Program, 11.

Khan, Y., O’Sullivan, T., Brown, A., Tracey, S., Gibson, J., Généreux, M., Henry, B., \& Schwartz, B. (2018). Public health emergency preparedness: a framework to promote resilience. BMC Public Health, 18(1344), 1-16. https://doi.org/10.1186/s12889-018-6250-7

Liberman, J., Levin, V., \& Luna-Bazaldua, D. (2020). Are students still learning during COVID-19? Formative assessment can provide the answer. UKFIET. Retrieved from https://www.ukfiet.org/2020/are-students-stilllearning-during-covid-19-formative-assessment-canprovide-the-answer/

McCabe, O. L., Barnett, D. J., Taylor, H. G., \& Links, J. M. (2010). Ready, willing, and able: a framework for improving the public health emergency preparedness system. Disaster Medicine and Public Health Preparedness, 4(2), 161-168. https://doi.org/10.1001/dmp-v4n2- hcn10003 
Mulenga, E. M., \& Marbán, J. M. (2020). Is COVID-19 the gateway for digital learning in mathematics education? Contemporary Educational Technology, 12(2), ep269. https://doi.org/10.30935/cedtech/7949

Naciri, A., Baba, M. A., Achbani, A., \& Kharbach, A. (2020). Mobile learning in higher education: Unavoidable alternative during COVID-19. Aquademia, 4(1), ep20016. https://doi.org/10.29333/aquademia/8227

Nelson, C., Lurie, N., Wasserman, J., \& Zakowski, S. (2007). Conceptualizing and defining public health emergency preparedness. American Journal of Public Health, 97(1), 9-1. https://doi.org/10.2105/AJPH.2007.114496

New normal [Def.1]. (2009). In Urban Dictionary. Retrieved on May 1, 2020, from https://www.easybib.com/reference/ guide/apa/dictionary

Ng, G. (2012) Disaster work in China: Tasks and competences for social workers. Social Work Education, 31(5), 538-556. https://doi.org/10.1080/02615479.2011.581277

Nitko, A. J., \& Brookhart, S. M. (2014). Educational assessment of students ( $8^{\text {th }}$ ed.). Pearson Education: New York.

Norberg, A., Dziuban, C. D., \& Moskal, P. D. (2011). A timebased blended learning model. On the Horizon, 19(3), 207216. https://doi.org/10.1108/10748121111163913

Obana, J. (2020, March 18). Could educational technology be a 'holy grail' amid Covid-19 crisis? The Manila Times. Retrieved from https://www.manilatimes.net/2020/03/18/ business/columnists-business/could-educationaltechnology-be-a-holy-grail-amid-covid-19-crisis/704202/

Olivier, W. (2020). Education post-COVID-19: Customised blended learning is urgently needed. The Conversation. Retrieved from https://theconversation.com/educationpost-covid-19-customised-blended-learning-is-urgentlyneeded-138647

Patrinos, H. A., \& Shmis, T. (2020). Can technology help mitigate the impact of COVID-19 on education systems in Europe and Central Asia? [Blog post]. Retrieved from https://blogs.worldbank.org/europeandcentralasia/cantechnology-help-mitigate-impact-covid-19-educationsystems-europe-and

Print, M. (1993). Curriculum development and design. Sydney: SRM Production Services.

Radwan, A., \& Radwan, E. (2020). Social and economic impact of school closure during the outbreak of the COVID-19 pandemic: A quick online survey in the Gaza Strip. Pedagogical Research, 5(4), em0068. https://doi.org/ $10.29333 / \mathrm{pr} / 8254$
Romano, L., Papa, L., \& Saulle, E. (2012). Awesome lesson ideas to integrate science across the curriculum. Teach $H u b$. Retrieved from http://www.teachhub.com/integratescience-across-curriculum

Secon, H., Woodward, W., \& Mosher, D. (2020). A comprehensive timeline of the new coronavirus pandemic, from China's first case to the present. Business Insider. [online]. 23 May 2020, 12, 31. Retrieved on May 24, 2020 from https://www.businessinsider.com/coronaviruspandemic-timeline-history-major-events-2020-3

Shereen, M. A., Khan, S., Kazmi, A, Bashir, N., \& Siddique, R. (2020). COVID-19 infection: Origin, transmission, and characteristics of human coronaviruses. Journal of Advanced Research, 24, 91-98. https://doi.org/10.1016/ j.jare.2020.03.005

Sintema, E. J. (2020a). Effect of COVID-19 on the performance of grade 12 students: Implications for STEM education. Eurasia Journal of Mathematics, Science and Technology Education, 16(7), em1851. https://doi.org/10.29333/ejmste/ 7893

Sintema, E. J. (2020b). E-Learning and Smart Revision Portal for Zambian primary and secondary school learners: A digitalized virtual classroom in the COVID-19 era and beyond. Aquademia, 4(2), ep20017. https://doi.org/ 10.29333/aquademia/8253

Taba, H. (1962). Curriculum development: Theory and practice. New York: Harcourt Brace Jovanovich.

Toquero, C. M. (2020). Challenges and opportunities for higher education amid the COVID-19 pandemic: The Philippine context. Pedagogical Research, 5(4), em0063. https://doi.org/10.29333/pr/7947

Tyler, R. W. (1949). Basic principles of curriculum and instruction. Chicago: University of Chicago Press.

Uhernik, J. (1998). The counselor and the disaster response team: An emerging role. In G. R. Walz, J.C. Bleuer, \& R.K. Yep (Eds.), Compelling counseling interventions: Celebrating VISTAS' fifth anniversary (pp. 313-321). Ann Arbor, MI: Counseling Outfitters.

Usak, M., Masalimova, R. A., Cherdymova, I. E., \& Shaidullina, R. A. (2020). New playmaker in science education: COVID19. Journal of Baltic Science Education, 19(2), 180-185. https://doi.org/10.33225/jbse/20.19.00

Valencia, M. I. C., Ali, M., Maryani, E., \& Supriatna, N. (2018, September). Integration of disaster risk reduction in the curriculum of Philippine educational institution. Paper presented at 3rd Asian Education Symposium. Retrieved from https://download.atlantis-press.com/proceedings/ aes-18/55917397 